\title{
ENVIRONMENTAL HUMANITIES IN PRE-SERVICE TEACHERS' EDUCATION
}

\author{
YOLANDA ECHEGOYEN-SANZ \\ Science Didactics Department, Faculty of Teaching, University of Valencia, \\ Avda. Tarongers, 4, 46022, Valencia, Spain. \\ E-mail address: yoesanz@uv.es \\ ANTONIO MARTÍN-EZPELETA \\ Language and Literature Didactics Department, Faculty of Teaching, Univer- \\ sity of Valencia, Avda. Tarongers, 4, 46022, Valencia, Spain. \\ E-mail address: anmarez@uv.es
}

\begin{abstract}
Aim. The aim of the research is to explore the possibility of integrating Sciences and Humanities in the Faculty of Education using Ecocriticism books and literary workshops with didactic activities of an interdisciplinary nature.

Methods. The experiment was carried out with 100 students of the Faculty of Education of the University of Valencia from the subjects Natural Sciences for Teachers and Literary Training for Teachers, where different didactic activities around two literary works, a novel and a short story, were proposed.

Results. After the activities, the vast majority of the students consider that Literature can help in the learning of Science. $41.7 \%$ of the students of Literary Training for Teachers and $62.5 \%$ of Natural Sciences for Teachers consider the integration of Sciences and Humanities in class "very important"; and 55.6\% and 29.2\% "quite important". More than $90 \%$ of the students said they were "very" or "quite" conscious of sustainability and environmental protection, although the percentages vary slightly between the two classes.

Conclusion. With this study we have shown that Ecocriticism and Education are two interlinked concepts, in the same way that literature and society are. The use of the socializing function of literature is when we can have greater educational performance in the current classroom, because it allows the students to connect their reality with the texts. These ecocriticism works are a first-order didactic resource to raise awareness about environmental and sustainability problems in pre-service teachers that will transmit the message to their future students.
\end{abstract}

Key words: Faculty of Education, literary workshops, ecocriticism, sustainability, environmental protection. 


\section{INTRODUCTION. AN INTERDISCIPLINARY INNOVATION PROJECT AT THE FACULTY OF EDUCATION}

There has been a change in the critical-literary currents, promoted by Cultural Studies that incorporates a practical and social end to the propaedeutic analyses. It has enlarged the corpus of study by adding works belonging to other artistic spheres, such as cinema. The extension of the recipients to different sectors (no longer only cult ones) has been shown as an extraordinary critical enrichment, which has manifested in various disciplines of great strength. Ecocriticism as a way to investigate the global ecological crisis through the intersection of literature, culture, and the physical environment is one of the most interesting movements among Cultural Studies. Its pragmatism is based on the fact that Ecocriticism does not stop in the observation of environmental problems in cultural products; but rather it is an exercise of reflection and awareness. Thus, we could say that Cultural Studies and Education is an indissoluble binomial. However, as Henry Giroux claimed more than twenty years ago in his important article "Doing Cultural Studies. Youth and the Challenge of Pedagogy" (1994), the necessary dialogue that must flow between the faculties of Education and the world of Cultural Studies has not yet intensified. In the English-speaking world, and regarding Ecocriticism, it is still far from satisfactory, as is stated by Orr (2004), Golemn, Benett and Barlow (2012), Saylan and Blumstein (2011) or Scott (2010).

In Spain the situation is similar. This type of ecocritical studies begin to emerge not only in departments of Literary Theory and Comparative Literature but also in departments of English Philology. However, their presence in departments of Romance Languages is scarce. There are, nevertheless, some initiatives like those of the Iberoamerican Association of Literature and Ecocriticism, the journal Ecozon@, or the GIECO research group in the University of Alcalá (see the works of Flys Junquera, 2010; Prádanos, 2015), although they still have not reached the Faculties of Education.

And this is strange taking into account that environmental protection is a cross-curricular competency in many curricula at the different Faculties of Education in Spain (Martínez Agut, 2007; Ull, et al., 2009). This competency is always approached from the Science point of view, with many interesting contributions (Vilches Peña, \& Gil Pérez, 2015). Ull et al. (2014), focusing their study on the University of Valencia, concluded that most of the faculty members are not interested in sustainability, and those who are do not know how to integrate the topic in their classes.

In the case of Humanities, there is a fruitful relationship between Literary Theory and Literature Didactics, as shown by Mendoza (2004), among others. However, the last step has to be to assimilate ecocriticism contributions and formulate their didactic transposition (according to Yves Chevallard's terminology, 1988), to improve the educational achievement. There are some studies exploring these possibilities as those of Martos y Martos (2016) or Martos, Campos \& Ezquerro (2017), in addition to some approaches to children's and 
young people's literature carried by Laso y León (2010) or Alves Bedendi (2011).

In this context the educational innovation project Sciences and Arts was born in the Faculty of Education of the University of Valencia in Spain (its web page can be visited at https://yoesanz.wixsite.com/cienciasyletras-uv). The project is constituted by nine professors of three different disciplines (three professors of Literature, three of Social Sciences, and three of Experimental Sciences) and aims to design didactic materials inspired by the integration of Sciences and Arts as well as to explore their educational possibilities with preservice teachers. To this end, the assimilation of ecocriticism studies and interdisciplinary approach are key factors.

From a pedagogical point of view, the proposed methodology is phenomenon-based learning (Symeonidis, \& Schwarz, 2016), which integrates knowledge and skills of many diverse disciplines around a key phenomenon. In this manner, phenomena such as climate change or biodiversity protection are not only studied from the Biology, Physics, Economy or Ecology points of view but also from History, Literature or Cinema. In short, the project Sciences and Arts is trying to develop a new way of teaching and to assess its performance and use.

\section{THE CONTEXT IN THE FACULTY OF EDUCATION AT THE UNIVERSITY OF VALENCIA}

The key of the didactic activities here presented lies in the fact that they have been implemented at the same time in prototypical subjects of Sciences and Humanities in the Faculty of Education, such as Natural Sciences for Teachers and Literary Training for Teachers. Both are subjects of the so-called 'basic', which are taught in the first courses of the Bachelor degrees in Early Childhood Education and Primary Education (at the University of Valencia, in both cases in the sophomore year). The idea is, therefore, to overcome the curricular organisation in subjects, departments or specialisation areas, and to demonstrate that literary texts are a first-order resource for working Sciences and that scientific content and reflection on environmental protection are not incompatible with literature classes. The assumptions of critical Pedagogy already highlighted the fact that renewing the processes of teaching and learning also requires changing the educational system. This so-called liberatory pedagogy (Shor, \& Freire, 1987; Giroux, 2004) is basically incompatible with an inflexible, tight and curricular system based on monographic studies and not on horizontal and interdisciplinary knowledge. In any case, the ultimate goal, as it cannot be otherwise, is to promote the knowledge of students in such relevant subjects as Language, Literature or Science; but always mixing together knowledge from those areas and subjecting them to a holistic, real and ethical training, including aspects related to Ecology and environmental protection, but also civic responsibility or empathy.

As we have previously mentioned (Martín Ezpeleta, \& Echegoyen Sanz, 2017), it is convenient to point out that the nature of the Faculty of Education is 
a good environment for the students, the teachers of the future, to internalise the benefits of a way of learning that is completely aligned with the reality of teachers in schools. And, beyond the curricula, the task of education professionals in schools is to integrate very heterogeneous contents and competences in their classes, which are not as tightly compartmentalized in subjects and specialties as in Secondary or Higher Education.

So the aforementioned phenomenon-based methodology is perfectly aligned with the professional work of future teachers, who often complain about not understanding the necessity or the usefulness of the technical knowledge they are taught in specialized subjects in the Bachelor degrees in Early Childhood Education and Primary Education, such as Language, Literature, Chemistry, Biology, Music, Psychology etc. Phenomenon-based learning allows, then, to break the departmental walls and subordinate all this technical knowledge in projects that help the students to answer that question and, as stated above, to internalise a new methodology that can be applied in their immediate professional work.

The experience here described was carried out during the academic year 2016-2017 with one hundred students from the Faculty of Education of the University of Valencia, distributed in two subjects: Literary Training for Teachers, taught by Antonio Martín-Ezpeleta, which is a 6 credits compulsory subject of the Bachelor Degree in Primary Education; and Natural Sciences for Teachers, also a compulsory subject of the Bachelor Degree in the specialties of Early Childhood Education and Primary Education, a 9 credits compulsory subject taught by Yolanda Echegoyen-Sanz. This context of applied Literature and Science, is precisely where, in our opinion, the world of Ecocriticism must be incardinated in the field of Education. Its hybrid scientific-literary nature, but above all its social and environmental protection vocation, means that the reading and comprehension of literary texts containing technical and ethical knowledge related to Ecology and sustainability is an excellent starting point to raise awareness in young people who are in charge of transmitting this message to thousands of children in their professional future. The issue has been explored in Children's and Young People's Literature, where there are books as successful as those of Jen Green and Mike Gordon (Why should I save energy?, Why should I protect Nature?, Why should I recycle?, or Why should I save water?); but the previous step to the use of these materials for children is to raise awareness among teachers, and in order to achieve that goal, it can be very useful to use texts such as the story Anaconda by Horacio Quiroga or the novel Sayonara Sushi by Raül Romeva, as we will immediately explain.

\section{DESCRIPTION OF THE ECOCRITICISM-BASED ACTIVITIES}

The short story Anaconda. In both subjects, the story Anaconda was read to develop different complementary activities. In the case of Literary Training for Teachers, the teaching unit began with the reading of only the first paragraphs of the story. These serve as a presentation of the plot, but do not include 
the protagonist, the eponymous character of Anaconda, but Lanceolada, who is a viper. Few students noticed this fact, and did not know that snakes are divided into vipers and snakes (like anaconda), which, as the story illustrates brilliantly, are two similar families, although with notable differences.

In this sense, many students learned in Literary Training for Teachers class that vipers inject poison to defend themselves, while snakes attack by asphyxia. They also realized that the latter are much larger in size and immune to vipers' venom, so they would be victorious in a hypothetical fight between them. Regarding their relationship with humans, it was also concluded that vipers are much more dangerous and, except in Hollywood films, snakes are more associated with pets, although big snakes can be dangerous for children, for example. Finally, all this information, which came up before the activity, was quickly connected by the students with the popular adventures of the Spanish television celebrity Frank de la Jungla (Frank of the Jungle), who can be also considered a science populariser.

It could be affirmed that there was a previous step of assimilation of biological information that served the students to develop the main activity of the didactic unit, the writing of their particular story of Anaconda, which had to be framed with the first and the last paragraphs of the original story provided by the teacher. The full story of Quiroga was only read at the end, when it served to contrast the prejudices and creativity of each student.

At this point, a small writing workshop was developed (on these, see the studies by Owens, 2001; Newcomb, 2012; or Savageau, 2013; the latter focused on environmental education), which involved sequencing the task of writing the story, inviting students to use and assimilate the narratology terms previously studied. Thus, we started from the differentiation between plot and story, making it easier for them to make decisions about the components (narrator, main and secondary characters, setting) and the plot (order, the sequencing of time, the speech of the characters, etc.). Therefore. they would not start from scratch, but from a series of answers to previous questions about the plot, which should also be condensed in a summary of the story they were going to write.

The truth is that most of the texts generated by the students shows how they understood the core of the story, despite the fact that Anaconda had not yet appeared. During the selection of the plot components, the teacher collaborated with the students, insisting on the narratology concepts and explaining how each decision is important and many times implies a change in the plot. In the same way, he also accompanied the writing of a part of the story, which preferably did not have to be the one that immediately linked to the original text; but for a key moment, the climax of their plot, which is the one that they had to make an effort to write with more connotation.

The activity concluded with the reading of some texts, which served to illustrate the creative possibilities, and were generally related to respect for the environment, preservation of biodiversity, and the harmful role that mankind often plays in the virgin forests. The activity concluded, as noted, with 
the reading of the original story, which was followed by the explanation of some notes on the work of Horacio Quiroga and its extraordinary importance in the History of short story, as well as the reflection on this figure that unites tradition with modernity. At this point, a small literary constellation was also drawn (Jover, 2009), which united the traditional fables with the theme of the so-called novels of the earth (the most famous is La Vorágine by José Eustasio Rivera). And there was also a place to synthesise the evolution of the genre of the modern story by Edgar Allan Poe and the chain that begins there and that links Horacio Quiroga and other authors of the Spanish-American boom such as Jorge Luis Borges, Julio Cortázar and Gabriel García Márquez, in addition to the novelist Alejo Carpentier and his everlasting Los pasos perdidos, which has a lot in common with the theme and authors mentioned. In short, a brief history of universal literature lesson, perfectly combined with literary theory concepts, which helped the students to connect with the narrative topics previously studied, in addition to other readings of several of the mentioned authors made during the academic year.

The result was positive. The students who like these practical classes knew how to use concepts, develop creativity, and connect these learnings with the most erudite notes that the professor offered, and it seems that the classes led to a significant learning, generated from known and lived experiences. Finally, through these narrative fictions students were able to empathize with the snakes, combating the traditional image that relates them to evil, and that has buried its necessary function in the food chain and even its direct benefits for the world of Medicine, which, as the students discovered in class, explain why their image is represented in the pharmacy logo.

On the other hand, in Natural Sciences for Teachers the students read the whole story before starting the activity. This reading was very relevant to develop issues of the thematic core of biodiversity, the one that was being studied. Specifically, it was used to illustrate aspects related to the second level of biodiversity, species diversity, because of the multitude of snake species that appear in the text. The relationship of these with mankind, which is constantly referred to as 'death' in the text, served perfectly to illustrate the loss of biodiversity by the direct action of human beings, one of the main environmental problems together with global warming, the overexploitation of natural resources or waste generation, all of them key aspects in this topic of sustainability and environment.

The activity, as in the case of Literary Training for Teachers, was based on creativity and writing workshops. In this case, working in pairs, they wrote a short story for children in which the main character had to be an animal and with a theme appropriate to raise awareness about an environmental problem of those studied. The students were invited to choose the main animal character, as well as the secondary characters, of whom they should describe their main physical and psychological characteristics.

Thus, stories were written about different types of terrestrial and marine animals. Incidentally, the most chosen animals for the role of heroes were 
turtles and bees. Generally, the plots included a main character who was a victim of human activities, although a couple of times an animal that polluted its own environment was also selected. Moreover, in most stories human beings adopted two different roles: on the one hand, those who were the cause of the problem suffered by animals; on the other, human beings, often children, who helped the animals and protected them from the negative action of some adults. It is curious to note that the vast majority of stories were developed in the current time (only a couple of them were located in the future, with an apocalyptic turn) and they took place in virtually all continents. Finally, perhaps due to the influence of the reading of Anaconda, some stories described assemblies of different animals that meet to find the solution to their problems.

Regarding the selected topics, the ones that appeared most frequently were pollution and waste, and deforestation and modification of ecosystems, although there were also stories that dealt with the loss of biodiversity, global warming, violence against animals, overexploitation of natural resources, or the use of pesticides. The created stories show how they assimilated scientific, literary and didactic information in an activity that was stimulating to the students.

The novel Sayonara Sushi. This novel (Romeva, 2012) was written originally in Catalan and translated immediately into Spanish. This work fictionalises the experience of the author as an MEP and environmental activist, especially in the defence of bluefin tuna. This is an endangered species (it has already disappeared in the Caspian and Black Seas), and is still being attacked by the strong fishing pressure, whose quotas are irresponsibly allowed by the great culinary performance of this fish in Japan. The problem, then, is not so much furtive fishing, but the connivance of the political leaders, who presumably do not put all the necessary measures to save this species.

The novel Sayonara Sushi is written according to the structure of detective genre. The title clearly refers to the 'farewell' to sushi, but also to the eponymous character of the novel, Paula, whose nickname is Sushi and who is a great lover of this Japanese dish. She is a journalist who travels to Malta to cover the news after reading a teletype about some African immigrants who saved their lives perched on a tuna cage when the boat in which they were trying to reach Europe capsized. There she meets Kira, a French mulatto MEP (the novel is sensitive to the themes of race, gender and sexual orientation) with whom she ends up having a romance (before, we had been informed of another relationship of the main character, heterosexual in this case). Thanks to this politician, she takes charge of the problem of bluefin tuna, which becomes her research topic, leading her to embark on the famous Greenpeace ship, Rainbow Warrior, to observe the struggle of activists against illegal fishing. In a parallel plot, another journalist, Mark Bonavia, investigates the political and economic interests surrounding the fishing of bluefin tuna, showing evidence of corrupt politicians and lobbies that pressure different countries to obtain a greater fishing quota without paying attention to biologists' reports. 
The novel, in short, does not stand out for its formal quality or originality. On the contrary, it seems to have a greater pretence of generating suspense and catching a popular reader. It wants to raise awareness about biodiversity protection in general, and the fishing of bluefin tuna in particular. This work could be considered as a juvenile novel, since it gathers all the prototypical components: detective plot, intrepid and young heroine, sexual encounters, violence etc. Technically, it is a very cinematographic work.

In this case, the activities carried out in the subjects Literary Training for Teachers and Natural Sciences for Teachers started from the reading of several passages of the novel, which were not exactly the same in both classes. In the first case, similar with the previous activity, it started with the first pages, with the idea that the students imagined how the novel could continue, using the creative strategies of Rodani (1985) to enhance imagination, and making it their own story. Then, other pages were read to show that the thematic knot revolved around the fishing of bluefin tuna and to show the problems involved, such as unmasking corrupt politicians.

After the reading, the teacher explained the plot of the novel and asked the students to modify it in order to turn the work into a real best-seller. Again, it was about enhancing creativity, sequencing the difficult task of writing in two phases: deciding what they liked and what they did not like about the plot (narrator's point of view, characters, settings, etc.), with the possibility of changing what they wanted (adding characters, episodes, etc.); and, secondly, writing the passage that they considered could be more relevant, placing it in the ordered plot. The curious thing is that they considered the topic of Ecology very interesting, and simply thought how to make the plot more intense, adding heroic speeches and more liaisons dangereuses, which sometimes distracted from the main issue.

The reception of the work was positive, and most of the students considered that ecological and environmental topics were interesting in the novel. The debate that took place on this issue showed that they were not oblivious to these problems, and that they thought it was key for children to become aware of them. However, there were not many from this class who said they wanted to read the complete novel.

In Natural Sciences for Teachers several fragments were also read, but this time focusing on the issue of bluefin tuna fishing, and explanations were offered about the aggression to the environment. From here, a double debate was generated: can literary texts be used in Natural Sciences classes? This was monopolised by the affirmative answer and the didactic opportunities that the students saw to work the topic in stories with children. And secondly: what other problems related to the environment do you know? In this debate arose issues such as pollution and the hole in the ozone layer, water waste or poaching of protected animals (bears, seals, etc.), which were completed with others introduced by the teacher in a creative activity.

A list of problems related to sustainability, the environment and food (another subject is nutrition and a balanced diet) was provided. After the stu- 
dents understood the idiosyncrasy of each problem, they chose one to prepare an activity of setting up a narrative plot and writing a summary (they were told to write the back cover of the book), which, in addition, should be accompanied by complementary didactic activities. The students chose mainly four problems, with hardly any differences between them: deforestation produced by palm plantations to obtain oil ( $28.1 \%)$; waste generation due to the excessive use of food packaging (21.8\%); animals conditions in intensive farming and the use of antibiotics and hormones (21.8\%); and endangered shark and stingray species due to their consumption (18.75\%).

The didactic activities designed from their literary texts were very varied and related to different areas of knowledge. As an illustrative example, A.B. wrote a short text addressed to children this time and designed activities aimed at Primary students: looking for information on sharks and seeing their contribution to the balance of the environment; sending a letter written by the students to the Spanish Federation on Fishing to create fish farms and reduce catches; carrying out a theatrical performance in class about the work; or showing in detail the statistics that indicate the problem that exists with the indiscriminate fishing of sharks.

Finally, as a general assessment, we would like to point out that in both subjects the students did not find it strange to work with the novel Sayonara Sushi and that they found the topic really interesting, despite the fact that not all of them liked the novel. In both cases, this reading was used to enhance different competences, some specific to the subjects, but also common ones of a creative, linguistic and ethical nature, for example. This educational experience served to demonstrate to these future teachers that the topic is important enough to deal with transversally, and from activities that entail to get involved in the solution.

To conclude the presentation of these activities, we also have the opinions of the students, which we briefly analyse in the following section.

\section{ASSESSMENT}

In order to monitor the experience, two questionnaires were filled in by the students, one before and one after the didactic activities, with some common questions.

Initial questionnaire. In the first questionnaire, the issue of the separation and possible integration of Sciences and Humanities was approached from closed questions, such as, for example, if they find the choice between Science and Arts easy in Secondary Education to which $64 \%$ answer affirmatively. Among other answers, it is surprising that the vast majority of students, $76 \%$, consider that the traditional separation between Sciences and Humanities is not adequate, which they sometimes argue with sound explanations like these: "They should be studied in a more integrated manner. We cannot use everything, but some scientific aspects for letters and vice versa. In life everything
\end{abstract}


appears together and in interaction, both Arts and Sciences" (S.D.); or "Both disciplines (although some people do not want to see it) are closely linked and they need each other to achieve what really matters: to learn, to understand, to create, to discover ..." (S.R.). Only $4 \%$ claim to have heard about ecocriticism, which the vast majority intuitively defines as "a critique of Ecology". Only a couple of students approach a correct definition: "literary current with scientific foundations" (A.G.) and "the relationship between Science and Literature, such as Nature and Literature" (A.B.).

Most students associate the snake with poison and danger, $49 \%$ and $41 \%$ respectively; although $7 \%$ relate it to medicine and 3\% to virtues such as cleverness or intelligence. In general students do not know stories where snakes are the main character. In addition, the majority, $71 \%$, anticipate that in the story of Anaconda these animals will be dangerous and harmful, with arguments like the following: "In all the stories the snake always plays the evil because it is considered a dangerous animal" (P.S); "Usually the snake acts as an enemy of man, therefore in many cases it is attributed an antagonistic role. Also in the Bible there is the passage where a serpent caused Adam and Eve to bite the apple and leave paradise" (E.A.). Those who answer that it will appear as a nice animal provide arguments, precisely, by contrast: "I think it will act differently to change our view of snakes since we have a negative view of them" (S.R.); "I think this story will pretend to make us see that the snake is not a bad animal, that it also has feelings and that it is just as valid as any other" (K.S.).

When asked why they believed that animals are used as characters, the majority response is because they call the attention of children to be "close", "nice" and "inspiring tenderness" characters. We reproduce here some opinions: "I think that the use of animals as characters is so that the works are more creative and imaginative and children connect better with these without anyone feeling directly identified and thus are able to transmit moral lessons, values, education..." (M.R.); "I think they put animals so that we associate or inculcate what role each animal has in society. For example, a donkey is always the fool, the turtle is slow, etc." (N.M.); "Because in many occasions it is a different and attention-grabbing way to convey a variety of feelings and values, and I believe that humans empathise with them positively if they are good, and negatively if they are dangerous" (A.L.).

Final questionnaire. The second questionnaire took up the same subject of Sciences and Humanities, but once the students had carried out the described activities. The following data are key: almost all of the students, 93\%, consider that Literature can help in learning Science; and the remaining 7\% do not have a formed opinion. Regarding the integration of Sciences and Humanities in class, $41.7 \%$ of the students of Literary Training for Teachers and $62.5 \%$ of Natural Sciences for Teachers consider it "very important"; and $55.6 \%$ and $29.2 \%$ "quite important". The reasons again are very indicative that the subject must be present in the curricula: "Because both are important for our lives, so it seems a fantastic idea to read a book that is about Science, because at the same 
time that you are reading, you are expanding your knowledge about something that you did not know but is interesting" (M.B.); "I believe in significant learning and, therefore, I believe that cognitive development is easier, more appropriate and solidly related to different areas of knowledge, based on the multidimensionality of learning" (V.A.).

Finally, after the activities, among Natural Sciences for Teachers students, $22.4 \%$ and $69.4 \%$ said they were "very" and "quite" conscious of sustainability and environmental protection. Among Literary Training for Teachers students, the percentages vary slightly: $38 \%$ and $57 \%$ respectively. Some of the students' proposed strategies to promote environmental protection with their future students are: "First of all, I think it is essential that they see what my attitude towards the environment is, since they tend to imitate the teacher. In addition, I would treat it as a transversal topic in the classroom, always being present and giving it the importance it deserves" (L.L.); or "Recycle in class, that each week they will contribute new ideas to recycle containers, make the future students see what they cause little by little if they do not take care of the planet and visually show the consequences and make a small debate so that they can have their own conclusions and solutions" (A.J.).

Again, more than $90 \%$ say that they would use literary texts in class to achieve that purpose, accompanied by arguments such as, "It would be a good resource. The activities of daily life require both linguistic and reasoning skills so it does not make much sense to work them as isolated areas. In addition, for those students who do not like science too much or find it difficult, it can help them to treat it as a story" (I.P.); or "Yes, through stories children learn many concepts that make them reflect on and think. Through the story a lot of interest is awakened, they like to hear them and concentrate on them, it is a great methodology to use in Early Childhood Education that benefits us when dealing with many areas and concepts" (L.Q.).

In fact, $46 \%$ of the students in the Natural Sciences for Teachers classroom included the activity of writing a story for children with an animal as a protagonist among the three that they liked the most during the whole course: "The activity that I liked the most was to write a book because I found it funny to see what my classmates had developed and how in our classroom when we are future teachers we will be able to teach our students indirectly to take care of the environment or the possible repercussions that misuse of resources may imply" (O.M.); "I really liked the activity of the children's story because it was a way of working the environment and sustainability in the school as future teachers that we are" (P.D.).

It seems clear that the activities stimulated them and that the students find interesting to continue delving into the issues of sustainability and the environment, as well as not to disconnect Sciences and Humanities, which help each other. The teachers cannot agree more. 


\section{CONCLUSIONS}

As Cultural Studies has strengthened, Ecocriticism and Education are two concepts that need each other, in the same way that literature and society are interlinked. Using this socialising function of literature, we can have a greater educational performance in the current classrooms, connecting the reality of the students with the texts.

The educational experiences here exposed aim to encourage the faculties of Education to be more permeable to these new directions of literary criticism, such as Ecocriticism. This is important because, although they are being acknowledged in the world of the Spanish literary theory, they are practically unknown in educational environments. Even this way of explaining literature, which focuses on its ethical and social aspects, is perfectly aligned with critical pedagogy and modern psycho-pedagogical and didactic assumptions.

There is a great responsibility when dealing with students at the Faculty of Education, because they are the teachers of the future and will influence thousands of children in their professional life. So we must take advantage of the educational spaces generated by the reading of texts related to nature and especially environmental protection, and for this purpose Ecocriticism works are the perfect choice. We should see the beginning of a new era with educational changes aimed at the development of a much needed sustainability awareness, as was the objective of the United Nations Decade of Education for Sustainable Development. In our hands is the task to implement teaching practices and prepare educational materials to achieve that goal.

\section{REFERENCES}

1. Alves Bedendi, M.L. (2011). Literatura infantil y educación ambiental. Contribución en la construcción de la identidad del ser humano [Children's literature and environmental education. Contribution to the construction of the identity of human beings]. Eventos Pedagógicos, 2(3), 59-69.

2. Chevallard, Y. (1988). On didactic transposition theory: some introductory notes. Communication, international symposium on research and development in mathematics education. Bratislava, August 3-7, 1988. Retrieved from http://yves.chevallard.free.fr/spip/spip/IMG/pdf/On_Didactic_ Transposition_Theory.pdf.

3. Flys Junquera, C., Marrero Henríquez, J.M., \& Barella Vigal, J. (Eds.) (2010). Ecocríticas. Literatura y medio ambiente [Ecocriticism. Literature and environment]. Madrid: Iberoamericana Vervuert.

4. Giroux, H. (1994). Doing Cultural Studies. Youth and the Challenge of Pedagogy. Harvard Educational Review, 64(3), 278-309.

5. Giroux, H. (2004). Cultural studies, public pedagogy, and the responsibility of intellectuals. Communication and Critical/Cultural Studies, 1(1), 59-79.

6. Golema, D., Bennet, L., \& Barlow, Z. (2012). Ecoliterate. How Educator Are Cultivating Emotional, Social and Ecological Intelligence. San Francisco: Jossey-Bass.

7. Jover, G. (Coord.) (2009). Constelaciones literarias. Sentirse raro. Miradas sobre la adolescencia [Literary constellations. Feeling strange. Looks about adolescence]. Sevilla: Junta de Andalucía.

8. Laso y León, E. (2010). La literatura infantil y juvenil: el nacimiento de una conciencia [Children's and young people's literature: the birth of a conscience]. In: C. Flys Junquera, J.M. Marrero Henríquez, \& J. Barella Vigal (Eds.). Ecocríticas. Literatura y medio ambiente [Ecocriticism. Literature and environment] (pp. 339-370). Madrid: Iberoamericana Vervuert. 
9. Martín Ezpeleta, A., \& Echegoyen Sanz, Y. (2017). La educación científico-literaria. Ecocrítica y sostenibilidad en la novela Sayonara Sushi de Raül Romeva [Scientific-literary education. Ecocriticism and sustainability in the novel Sayonara Sushi by Raül Romeva]. Letras Hispanas, $13,270-285$

10. Martínez Agut, M.P., et al. (2007). Promoción de la sostenibilidad en los currícula de la enseñanza superior desde el punto de vista del profesorado: un modelo de formación por competencias [Promotion of sustainability on higher education curricula teachers' point of view: a model by competences]. Educatio siglo XXI. Revista de la Facultad de Educación, 25, 187-208.

11. Martos Núñez, E., \& Martos García, A. (2016). La perspectiva performativa en las ciencias sociales y en las prácticas alfabetizadoras de educación ambiental, literaria y patrimonial [The performative perspective in social sciences and literacy practices of environmental, literary and heritage education]. Caracteres. Estudios culturales y críticos de la esfera digital, 5(1), 10-40.

12. Martos Núñez, E., Campos Fernández-Figares, M., \& Martínez Ezquerro, A. (2017). Superando la dicotomía entre humanidades y ciencias. De las narrativas míticas a la difusión científica a través de la cultura del agua [Overcoming the dichotomy between humanities and sciences. From mythical narratives to scientific dissemination through the culture of water]. CTS. Revista iberoamericana de ciencia, tecnología y sociedad, 12(35), 177-182.

13. Mendoza, A. (2004). La educación literaria. Bases para la formación de la competencia lectoliteraria [Literary education Bases for the formation of lectoliterary competence]. Málaga: Aljibe.

14. Newcomb, M. (2012). Sustainability as a design principle for composition: Situational creativity as a habit of mind. College Composition and Communication, 63(4), 593-615.

15. Orr, D. (2004). Earth in Mind. On Education, Environment and the Human Prospect. Washington DC: Island Press.

16. Owens, D. (2001). Composition and Sustainability: Teaching for a Threatened Generation. Urbana: NCTE.

17. Prádanos, L.I. (2015). The Pedagogy of Degrowth. Teaching Hispanic Studies in the Age of Social Inequality and Ecological Collapse. Arizona Journal of Hispanic Cultural Studies, 19, 153-168.

18. Quiroga, H. (1991). L. Fleming (Ed.). Cuentos [Stories]. Madrid: Cátedra.

19. Romeva, R. (2012). Sayonara Sushi [Goodbye Sushi]. Barcelona: Plaza y Janés.

20. Savageau, A.E. (2013). Let's get personal: making sustainability tangible to students. International Journal of Sustainability in Higher Education, 14(1), 15-24.

21. Shor, I., \& Freire, P. (1987). A pedagogy for liberation: Dialogues on transforming education. Westport: Greenwood Publishing Group.

22. Symeonidis, V., \& Schwarz, J. F. (2016). Phenomenon-based teaching and learning through the pedagogical lenses of phenomenology: The recent curriculum reform in Finland. Forum Oświatowe, 28(2), 31-47.

23. Ull, À., et al. (2009). La formación de competencias básicas para el desarrollo sostenible: el papel de la Universidad [The training of basic competences for sustainable development: the role of the University]. Revista de Educación, 1(extra), 219-237.

24. Ull, À., et al. (2014). Preconcepciones y actitudes del profesorado de Magisterio ante la incorporación en su docencia de competencias para la sostenibilidad [Preconceptions and attitudes of teachers of the Faculty of Education before the incorporation of competencies for sustainability]. Enseñanza de las Ciencias, 32(2), 91-112.

25. Vilches Peña, A., \& Gil Pérez, D. (2015). Ciencia de la Sostenibilidad: Una nueva disciplina o un nuevo enfoque para todas las disciplinas? [Science of Sustainability: A new discipline or a new approach for all disciplines?]. Revista Iberoamericana de Educación, 69(1), 39-60. 